\title{
Displacement, integration and identity in the post-colonial world
}

\begin{abstract}
Defining the relationship between displaced populations and the nation-state is a fraught historical process. The Partition of India in 1947 provides a powerful example. However markedly little attention has been paid to the refugee communities produced (Ansari, 2005). Using the case of the displaced 'Urdu-speaking minority' in Bangladesh this article considers what contemporary discourses of identity and integration reveal about the nature and boundaries of the nation-state. It reveals that the language of 'integration' is embedded in colonial narratives of 'population' versus 'people-nation' which structure exclusion not only through language and ethnicity, but poverty and social space. It also shows how colonial and postcolonial registers transect and overlap as colonial constructions of 'modernity' and 'progress' fold into religious discourses of 'pollution' and 'purity'. The voices of minorities navigating claims to belonging through these discourses shed light on a 'nation-in-formation': the shifting landscape of national belonging and the complicated accommodations required.
\end{abstract}

Keywords: Identity; Integration; Citizenship; Postcolonial; Displacement; Bangladesh; 


\section{Introduction:}

Displacement of population is a phenomenon of increasing political significance across the contemporary world. The Partition of India in 1947 provides a defining historical example, but the Indian subcontinent's experience of displacement and its longer term social and cultural consequences has been neglected in academic research. Considering the numbers displaced by Partition, and the sustained historical interest in the period, markedly little attention has been paid to the refugee communities it produced (Ansari, 2005). With growing scholarly interest in transnational phenomena, population movement from South Asia has attracted more attention, but the emphasis has been on those who migrated overseas, overlooking far greater movements of displaced within the subcontinent itself (Ahmed et al, 2004). As Zamindar (2007, p.6) argues, this is because 'in the region's nation-bound historiographies these refugees have been presumed to have seamlessly folded into new nations'. Large-scale displacement lay at the foundation of Indian and Pakistan and the refugee became a crucial symbol of their respective nationalist projects (Daiya 2008). However, defining the relationship between refugees and the nation-state has been a fraught historical process. This is particularly apparent in the case of East Bengal where many of Partition's refugees were displaced for a second time less than 25 years later. Bangladesh's Liberation War in 1971 produced one of the great internal migrations of the twentieth century and one of the greatest war-related migrations ever known (Kamuluddin, 1985). In present day Bangladesh the minorities remain, and they continue to navigate uneven claims to rights.

The 'Urdu-speaking population' of Bangladesh is one example, many of whom remain in camp-based settlements constructed across the country in 1972. Thought to have sided with the Pakistani forces in the Liberation War, they were made 'stateless' following the birth of Bangladesh. Today, assimilation into the Bengali majority is the only frame through which their equality can be conceived. Academic interest in the integration or assimilation of minorities in this region has, however, been limited. Any interest there is, is often considered in terms of law and policy, taking the perspective of the state and nation, animated by concerns regarding numbers, national security and international relations. As Ahmed et al (2004) observe, this tells us little about dislocated people, and little about the 'identity work' which structures acceptance and belonging in everyday life. I argue that the perspective of the nation is fundamental to the experience of those displaced, but that the boundaries of the nation are brought to life at the level of the individual. Using the case of the 'Urdu-speaking minority' in Bangladesh, therefore, this article considers what contemporary discourses of identity and integration can reveal about the nature and boundaries of the nation-state.

Having formally acquired citizenship in 2008 the political, civil, social and economic rights of the 'Urdu-speaking minority' in Bangladesh are still highly contested. In the use of words such as 'mixing', 'hiding' and 'passing', informants referred to, aspired to and evoked ideas of assimilation as the solution to social exclusion. The article looks in particular at the interface between these processes of 'mixing' and ideas of 'improvement', 'respectability', 'development' or 'progress'. In doing so, it makes three distinct points: first that the language of 'integration' is embedded in colonial narratives of 'population' versus 'people-nation', 'community' versus 'citizen' which structure exclusion not only through language and ethnicity (as commonly assumed) but through poverty and social space. Second that colonial and postcolonial discourse complicate and builds upon each other, and today, colonial constructions of 'modernity' and 'progress' fold into religious discourses of 'pollution' and 
'purity'. Third that the voices of minorities navigating claims to belonging through these discourses shed light on a 'nation-in-formation': the shifting landscape of national belonging in contemporary Bangladesh and the complicated accommodations this requires.

The research on which this article is based was conducted between 2008 and 2009 and on a return visit in 2013. It involved 64 in-depth semi-structured interviews (37 of which were with 'Urdu-speakers' living in camps and 27 of which were with non-camp based 'Urduspeakers'), 11 case study narrative interviews with individuals from three families whose histories reflected particularly interesting examples of movement between the camps and outside, 15 semi-structured interviews with local community leaders and political representatives, one civil society focus group, and sixteen months participant observation. Access was gained with the help of Al Falah Bangladesh and the Shamshul Huque Foundation. The interviews were conducted in Urdu, Bengali and English depending on the participants' preference. Two field sites were chosen in the capital Dhaka (Mohammadpur in the centre and Mirpur in the suburbs) and one in Saidpur, in the northern Rajshahi district. I begin by exploring the specific and located histories of citizenship in South Asia, before contextualizing the case of the 'Urdu-speaking minority' in Bangladesh. In the second section I draw on their voices to explore the multiple meanings and discursive registers through which integration and national belonging have been understood.

\section{Citizenship and nationhood in East Bengal: the shifting politics of identity}

The representation of citizenship as the unique foundation or invention of the West is integrally connected to the production of orientalism (Isin 2005). The diversity of ways in which the concept has been thought about and practiced in the colonial world cannot be overstated. As Kabeer (2002) suggests, differences are critically bound up with prevailing material realities and associated ideas about personhood. Citizenship in India should, therefore, be understood as the result of specific historicities of political discourse and procedure (Hansen 1999) through which unique and located state-citizen relations were produced. Here, customary law and traditional authority were invoked to support the hierarchical ordering of society, and differences of property, religion and caste were used to pre-empt the possibility of a unified resistance. Because the paramount concern of India's colonial regime was the (limited) representation of 'communities' through elite figureheads, the discourse of rights was applied almost entirely to collectivities (Hansen 1999). As Kabeer (2002) argues, therefore, colonised populations in South Asia achieved national independence as religious, ethnic and tribal communities with collective rights, rather than as individual and free citizens.

Additionally, while a range of differentiated categories then became the basis on which political claims were made and recognised, colonial rule in India was organized around a 'double discourse' that positioned the mass of ordinary people - uneducated, 'irrational', traditional and therefore in need of firm governance - against a relatively small section of educated, propertied, middle classes who were amenable to reasoned negotiation (Hansen 1999). This educated middle class were thought capable of behaving like responsible quasicitizens while 'ordinary Indians' were deemed governable only through the management and control of their 'irrational' religious passions. As a result, these 'educated sections' were entrusted with local administration and accorded certain rights of political representation that 'ordinary Indians' were not. Inscribed in the law, the economy and in (the absence of) rights was the division between an educated respectable 'people-nation' and the uneducated 'uncivilised' 'mass' (Hansen 1999). 
Neither India nor Pakistan were entirely new states in 1947 and many of the technologies of governance lived on into the post-Independence period. For decades educated 'society' was managed through law and rational procedure while popular 'communities' were controlled (Chatterjee 2005). Moreover, as Zamindar (2007) explains, with state formation taking place alongside large-scale displacement, definitions of citizenship were shaken to the core.

\section{'Urdu-speakers' in East Pakistan}

Around 18 million people were forced to leave their homes in the first two decades after Partition. Of that number an estimated one million were Urdu-speaking Muslims who migrated to what had become East Pakistan (Ghosh 2004). Coming from West Bengal, Orissa, Bihar, Jharkhand and Utter Pradesh some spoke Urdu, some Hindi, some Bhujpuri and some Bengali but state classification collapsed such distinctions and, when not classified as 'Muslim refugees' or 'mohajirs', they were all regarded as 'Urdu-speakers' (Rahman and Van Schendel 2004). West Pakistan's military and political dominance bought with it a religious nationalism that linked the authority of the state to a modernist interpretation of Islam that disavowed ethnic solidarity seen as endangering Muslim unity (Verkaaik, 2001). In reality, however, language (Urdu) played an important part in national self-definition and consequently 'Urdu-speaking' incomers gained increasing influence.

Many of those who formed the first wave of migration were employees of the colonial government who had been asked to choose which country to serve (Ilias 2003). Some took advantage of the opportunity to advance themselves professionally and moved with their families to urban centres like Dhaka and Chittagong. Others slightly lower down the pecking order, including skilled and white collar workers, often moved to the district towns and divisional headquarters nearest to them. After Partition, and particularly under General Ayub Khan's regime (1958-1969), the Pakistani state began to invest in industry, infrastructure and housing (Chatterji, 2010). A further group of migrants came from artisan communities or the better-off working classes. These migrants were weavers, masons, plumbers and carpenters, and they possessed many of the skills in demand in the new 'national' industries (Chatterji, 2010).

Refugee rehabilitation figured prominently in the attempt of both new states to establish legitimacy. Development plans projected the figure of the refugee as their central subject, who 'through the discursive and institutional regimes of rehabilitation, was made into a citizen of the nation' (Zamindar, 2007, p.9). Money was always disproportionately allocated to the West but housing colonies were built for 'Muslim refugees' in Mohammadpur and Mirpur in Dhaka as well as Chittagong, Khulna and Rajshahi district (Rahman, 2003). From 1951 to 1971 the Government of Pakistan imposed a 'Refugee tax' to pay for this rehabilitation. At this point 'Urdu-speaking migrants' occupied a privileged position as, through such processes, the ownership of property made and marked the citizens of this new state (Redclift, 2013b).

'Mohajirs' had influenced the growth of Islamic politics in East Pakistan. However, during the 1950s and 1960s sentiment towards these incomers shifted. Power had been monopolised by the West Pakistani elite since the country's inception (Kabir, 1995) and the exploitation and impoverishment of East Pakistan, and the local Bengali population, galvanised public support around the Bengali language and identity. Language-based Bengali cultural nationalism began to displace Islamic solidarity and from 1952 the Bengali language 
movement became a powerful force (Ghosh, 2004). Over time Urdu-speaking migrants began to be considered 'conduits of the West Pakistani colonialists' and derogatively known as 'Biharis' ${ }^{3}$. Tensions eventually culminated in the Liberation War between March and December 1971 in which as many as three million Bengalis are thought to have been killed (Paulsen 2006). Some 'Urdu-speakers' had been organized into the infamous paramilitary 'Peace Committees' and 'Razakars', who are thought to have been responsible for some of the worst atrocities of the war. ${ }^{4}$ Following the birth of Bangladesh in December 1971, the entire 'Urdu-speaking community' were branded Pakistani collaborators and socially ostracised. Through the 'Bangladesh Abandoned Property Order' of 1972, designed to dispose of 'enemy property', the appropriation of 'Bihari' homes was legalised. Having lost land, property and family members, many ended up in temporary camps which emerged across the country. Over forty years later these camps remain.

\section{Camp-dwellers in Bangladesh}

From 1972-2008 the 'Bihari' population of Bangladesh was recognized as 'de facto stateless' by the international community. Camp residents were unable to access government schools, government hospitals and government jobs. They were unable to hold a trade license, a driving license, open a bank account or buy and sell property. They lost the right to vote and without identity documents were unable to travel. Moreover, in the aftermath of 1971 they were not officially recognised as refugees by $\mathrm{UNHCR}^{5}$ and, as such, they achieved a sort of reduced form of protection. This included free electricity, water and a subsidized ration of rice which was suspended in 2004 but no meaningful protection from international law ${ }^{6}$.

In 2006, a local NGO recorded 116 'Urdu-speaker settlements' (sometimes known as 'Stranded Pakistani camps') in Bangladesh, housing 151,368 residents in total (Al Falah 2006). These camps were not established or governed by humanitarian organisations. In Dhaka only one camp, Geneva Camp, was formally built by the International Committee of the Red Cross (ICRC). The others were constructed on any land left vacant, and their names 'Cinema Hall Camp', 'Football Ground Camp' etc - attest to the desperate ad hoc search for shelter. Over the last forty years the simple bamboo structures have grown in scale and complexity, developing into situated local economies of enormous variety. ${ }^{7}$ There are no authorities to report to and residents can come and go as they please. They can move out of the camp if they are able to save the capital to buy land or rent a flat and, having moved out, some 'Biharis' have even been able to sell or lease camp properties for income. As a result, it is thought that today as many as $25 \%$ of camp residents in Dhaka may in fact be ethnically Bengali.

It is also now recognized that not all 'Urdu-speakers' in Bangladesh live in camps, as had been commonly assumed (camp residents will be referred to as 'insiders' for the purposes of this article). It is thought that as many as 100-300,000 have been able to establish themselves outside the camps, integrated to varying degrees with majority Bengali society. Some of these individuals moved into the camps following the war but have since acquired the capital to leave (referred to here as those 'in between'). Others avoided dispossession altogether through the wealth, status or connections they were able to claim (referred to as 'outsiders'). These 'outsiders', many of whom are successful professionals, entrepreneurs and even local councillors, have been accepted in Bangladeshi society for many years. Most 'outsiders' never actually lost their civil status following the war; they were accepted as citizens in all substantive respects, including in relation to some of the more symbolically salient rights 
such as voter registration, as well as the dominant 'markers' of such rights such as passports (Redclift 2013a).

\section{A 'nationalizing state': spaces of in/exclusion}

The creation of Bangladesh in 1971, in the name of cultural and linguistic Bengali nationalism, signalled the sidelining of religion from the political scene (Hashmi 2004). The secularism of the country's first Prime Minister, Sheikh Mujibur Rahman (1972-1975), 'did not mean the absence of religion' but religion became a 'ghost of the past one did not know how to deal with' (Ahmed 2002 p.302). It was replaced instead with the founding principles of nationalism, secularism, socialism and democracy, and a cultural (Bengali) identity was embedded at the very heart of the state. Following the war, the nation could not comprehend the possibility of multiple identities, and in pursuing the agenda of ethno-linguistic nationalism, all other identities were weakened (Samaddar 2002). Unlike India, which has at least officially upheld a policy of multiculturalism, in Bangladesh a Bengali ethnic identity was written into the constitution from its birth ${ }^{8}$. As Samaddar (1999) argues, the 'smaller' interests were sacrificed for the 'larger' interest of the nation, the bi-products of which were 'minorities', 'aliens'. 'Urdu-speakers' - implicated at the very heart of the language struggles preceding Liberation - became the exemplary national 'other'.

Bangladesh has however been described as a 'nationalizing state': not yet sufficiently a nation, but continually 'nationalizing' in the name of legitimacy (Samaddar 1999). Following the religious nationalism of the Pakistani period and the ethno-linguistic movements of the 1950s and 60s, the assassination of Sheikh Mujib by a military coup d'état in August 1975 heralded the search for a nationalism that could combine the two. The overthrow of Mujib's government signalled the turn to a resolute 'Bangladeshi nationalism' under General Ziaur Rahman (Zia), a shift of emphasis between the country's 'secular Bengali identity' and its 'Muslim consciousness' (Osmany 1992). Some argue that the move to assert a unified religious identity once again was caused by the fear of

Indian domination as well as the failure of the Awami League government to respond to the economic grievances of the population (Kabir 1987). Others suggest that 'political Islam' was adopted to contain more militant versions promoted by Jamaat-i-islami ${ }^{9}$, and that Mujib's successors realized the importance of state-sponsored Islam in the legitimation of their rule (Hashmi 2004). Whichever is more accurate, the role of Islam at the centre of politics and culture developed from 1975 onwards, and it became the state religion in 1988. With these changes the position of Urdu-speaking 'outsiders' altered too. Unlike those in the camps, they were not disenfranchised in 1972 but, according to interviewees, it wasn't until 1975 that treatment towards them began to improve (Redclift, 2013a). With the death of Liberation's figurehead, the changing role of religion in politics, combined with their own assimilation, a place within the nation was more securely assured.

Little changed for those inside the camps however; segregated from Bengali society, camp residents could not even access social and economic rights such as education and healthcare let alone claim the civil and political rights 'outsiders' enjoyed. It was not until almost thirty years later, in 2006, that the question of their citizenship was put back on the political agenda. In the context of a growing pro-democracy movement in Bangladesh, political instability ${ }^{10}$ brought with it the opportunity to look at the case afresh. Under a newly installed Caretaker Government the elections planned for December 2008 (and the introduction of the National ID system) galvanized the Election Commission towards a 
clarification of their status. Accordingly, in May 2008, after nearly 40 years of statelessness, the entire 'Urdu-speaking population' were granted citizenship by the High Court of Bangladesh. The decision has since been considered 'a major success in the campaign to end 'statelessness' around the world' (Refugees International, 2008).

In fact, this ruling drew attention to the disparities of civil status among 'Urdu-speakers' that had preceded it. For 37 years laws of 'ius solis' and 'ius sanguinis' (both of which have recognised legal value under the Citizenship Act of 1951 and Citizenship Order of 1972) were undermined by a civil status effectively constituted on socio-spatial (camp and non-camp) grounds. As a result, the social and economic divisions between the camp and non-camp communities have grown considerably. Furthermore, despite having formally acquired citizenship in 2008 the political, civil, social and economic rights of those in the camps are still contested. There has been an opening up of access to education since 2008, but informal discrimination continues to restrict employment. Equally, while voter registration prior to the 2009 election was considered an unexpected success ${ }^{11}$, many camp residents are still facing problems accessing legal documents, such as passports.

It has been argued that membership in the state grants one the status of a citizen, and membership in the 'nation' makes one a national. The ideals of the nation-state, however, conjoin the two (Bloemraad, 2000). The traditional 'unitary' model of citizenship assumes that the political and cultural spheres of membership are aligned so that every citizen is also part of the nation. As such, the individual's membership in a political community is dissolved into a collective 'cultural' identity, which for some still limits real access (Yuval-Davis et al, 2005). It has been commonly assumed that it is this collective cultural identity which limits the access of 'Urdu-speakers' to the nation-state in Bangladesh. However, as my research reveals, this collective cultural identity is accessible to some 'Urdu-speakers', if not others. Today colonial and postcolonial discourses structure inclusion and exclusion not only through language and ethnicity, but through poverty and social space. The belonging of 'Urdu-speakers' relies on social, cultural and economic assets through which acceptance in the national life of Bangladesh is achieved.

\section{The integration of 'Urdu-speakers'}

In the narratives of informants, one thing was desired by nearly all. The value placed on 'integration' was striking, and access to social, cultural, economic and 'symbolic capital' (Bourdieu 1979) was continually expressed in its terms.

\section{Social and economic capital: 'dirt' and 'development'}

In the camps of Mirpur, Mohammadpur and Saidpur poverty was a severe source of stigma, and the appropriate remedy always involved 'movement outside'. Some access to economic capital has always been necessary for movement outside the camp to take place as money to rent a flat and pay electricity bills is required. However, as residence in the camps limited access to education and employment, it limited access to economic capital too. In doing so, it limited the possibility of 'capital movements' through social space:

Here in the camp social status ('awqaat') can't change...everyone knows everyone's background...but when you move outside your social status changes, yes it's natural; you are living in a good place. You measure yourself as elite from living outside the camp and so do others (Tanvir, 'in between', around 30, Dhaka). 
However, social integration is more complicated than simply a question of physical possibility. It requires not only a 'good place' to live but the education and relationship building that comes with it. In Hussein Kardar's terms, this is the process of 'development':

When you move out (of the camp) you leave your social status behind and that makes it easier for relationships with people outside... moving out of the camp is useful for development. The camp creates a bar to social status (Hussein Kardar, ward commissioner, Saidpur - emphasis added).

For many of those in the camp, therefore, integration was understood in terms of the 'improvement' through which acceptance could be achieved (Skeggs 1997). As one campdweller explained, without such 'improvement', families could be split down the middle:

I don't feel bad that (my relatives outside) are in a better position (than me)...The only thing that makes me feel bad is when I think about how backward we are in comparison. We are very backward in comparison to them. Several times we faced many problems...(and) we aren't having education to improve our capacity here...They have fear to introduce us to their society...Just because of living in the camp my blood relation refuses me (Delwar, 'insider', 50, Saidpur-emphasis added).

Delwar uses the term 'backward' to position himself against the 'educated respectability' of 'Urdu-speakers' outside. Here, the 'double discourse' of Bengal's colonial past resonates still. The distinction between, 'the bounded, parochial and therefore innocent masses, and the essentially mobile, knowledgeable, modern and supposedly responsible national elite' (Hansen, 1999, p.39) divides the 'Urdu-speaking community' in social space. It wasn't just the space of the camp which divided 'Urdu-speakers' in such a way. Bodies themselves were sites upon which distinctions could be drawn, and clothing in particular enabled identification of and with the 'other' (Skeggs 1997). The dirty (disrespectable) body not only classified 'camp-dwellers' as poor, it also classified them as 'Bihari'.

VR: Are there any visible differences between a camp-dweller and an outsider?

Md. Shahid ('insider', 37, Dhaka): It is clean clothes that identify you as an 'outsider'...they think Biharis are dirty.

The body of 'respectability' is clean. Outside the camp, in 'good clothes', 'Urdu-speakers' are treated as equal but inside they are like 'slum-dwellers', dirty:

Some of them outside look down on us; they think people living in the camp are living in a slum. Bengalis too see us differently because those that live outside have a good place to live and are getting education, but we are slum dwellers, dirty (Saad, 'insider', 28, Dhaka).

They are discriminated against therefore in part as a result of their likeness to Bengali slumdwellers (their poverty, lack of education, 'dirt'), but also in a way that Bengali slumdwellers are not.

If you're from the camp when you try to get admitted into hospital they don't treat you well, but when you live outside and have better society ('acchi mahol') they treat you better. I saw often in the hospital people saying, 'they're Bihari, they are very dirty, leave them alone (don't treat them)'. We are human beings also! (Mala, 'insider', 34, Dhaka) 
Socio-economic and ethnic discrimination are brought together in the camp. If economic capital is acquired and movement outside achieved, ethnic identity itself assumes a different meaning:

I am very keen to move outside the camps. If I get the opportunity, start earning enough, I will move...those that live outside the camps are treated better by Bengalis. A person who lives outside if he is a Bengali or an Urdu-speaker it doesn't matter, they are treated as equal. If you have relatives outside the camp they don't want to associate with you because it indicates who you are, your status ('awqaat') (Shamim, 'insider', 28, Dhaka - emphasis added).

Movement outside provides the security and freedom that is derived from the possibility of being, in Malkki's (1995) term, 'socially unmarked'. In this context, social marking codes ethnic marking; the spaces themselves have become integral to the manner in which ethnic identity is defined (Keith, 2005). Ethnic identities constructed in opposition to national identities are, therefore, situated in the camp (Redclift, 2011).

The process of becoming 'socially unmarked' was articulated as much in relation to ideas of education and 'society', as it was in relation to property or wealth. Bourdieu's 'social relations of capitals' is, therefore, a conceptual frame well suited to the dynamics I am describing in part because of the composite criterion it invokes; helping us to understand how social positions intersect and interact in subjective production. In the social, spatial and historical specificity of the camp, movements through social space are not impossible and, as informants revealed, a 'Bihari' identity was one that could be re-configured. In fact, the mutability of ethnicity within the times and spaces in which identities are staged is made very clear (Keith, 2005). After all, just as the nation is created through historicising, so is ethnicity a product of historical circumstances and political projects.

It has long been suggested that the search for a collective Bengali Muslim identity has historically been caught between the competing pulls of a local 'Bengali' linguistic and cultural tradition and an (extra-territorial) 'Islamic' identity (Roy, 2001). As Brubaker (2012) asserts, language and religion are arguably the two most consequential domains of cultural difference in the modern world. In Bangladesh, they form the focus around which projects of nationalism continue to move and, therefore, around which discourses of 'cultural integration' orbit.

\section{Cultural capital: 'purity' and 'pollution'}

A central requirement of the modern nation-state is the institutionalisation of a chosen national language. The Liberation War fought against the institutionalization of the Urdu language and, in its aftermath 'Urdu-speaker' became a pejorative term. However, following the war, a Bengali cultural and linguistic identity was woven into the structuring principles of the state. Furthermore, despite the fact that protection for linguistic rights, observed in the Universal Declaration of Human Rights, is made binding through Bangladesh's recognition of the UN Charter, Article 28 (1) of the Bangladeshi Constitution remained notably silent on the issue:

The state shall not discriminate against any citizens on grounds only of religion, race, caste, sex or place of birth.

Language was mapped onto a vision of national identity in such a way that today, the ability of 'Urdu-speakers' to speak Bengali significantly influences opportunities and expectations. 
At the same time, the socio-economic polarisation of 'Urdu-speakers' inside and outside the camps since 1971 has been reproduced in widening disparities of language use. Not only do those living outside the camps speak better Bengali than those inside, but they also have a very different relationship to the one thing that is meant to connect them - Urdu. The older generation of 'outsiders', wealthy and well educated, speak a fairly 'standardized' Urdu, while the Urdu of the camps is more often described as a language 'variety'. Sometimes referred to as 'Indian Urdu' or 'hodgepodge' it a mixture of Urdu-based regional dialects such as Bhujpuri and Magadhi fused together by the sudden cohabitation of migrants from all over India (Ilias 2003). As 'outsiders' explain, 'The language of the camp is a language of its own' (Shamim, 'outsider', 53, Dhaka), in relation to which purity and value are highly contested:

I would describe the kind of Urdu I speak as mixed ('milawat'), muddied/no longer pure ('bejhal') (Mohammad, 'insider', 30, Dhaka).

In the camps we are speaking the Urdu which is valueless. It is Urdu 'dust', 'rubbish' ('dhula')...they (those outside) can't understand us...and they say my Urdu is valueless (Salma, 'insider', 18, Dhaka).

The continuing significance of regional dialects such as Bhujpuri within the camp variety suggests some degree of congruence with pre-1971 social dialectical form, but when the camps were first established they clearly housed a broader assortment of social positions than today. In 1972 schooling came to a virtual standstill, and once those who had been educated in 'standard' Urdu died or left, the language was no longer taught. The younger generation of the camps speak Bengali alongside the camp dialect because they spend much more time outside the camps than older residents, but here linguistic purity is again a recurring theme. Many 'outsiders' were keen to emphasize that the Bengali they spoke was not like the Bengali of those in the camps:

As we have better link with Bengalis, Bengali professors etc, in my family we speak 'pure Bengali' (Jabuddin, 'outsider', 30-40, Dhaka).

As with Urdu, the form of Bengali spoken is influenced by education and social status and through language a distance is drawn between 'outsiders' like Jabuddin and those 'inside'. 'Pure Urdu' itself reveals a certain level of wealth and education, but 'pure Bengali' is an even more powerful symbol of status. It represents wealth and education with the social and cultural capital of integration combined. Many of those who moved outside the camps took great pride in their newfound language skills:

(Since I moved outside) Now I can speak good Bengali, I used not to speak clearly. It has affected the way people treat me...If you speak Bengali you are treated better (Tuni, 'in between', 27, Dhaka).

Moreover, the cultural capital provided by language and the economic capital provided by employment cannot be seen as independent of each other:

Those Biharis who can speak Bengali and can give bribe, they manage a job. But not the rest of us (Farhana, 'insider', 70-80, Saidpur).

Alongside language skills, broader access to 'Bengali culture' affords cultural capital of its own. As discourses of Islamic unity have re-emerged in the wider social context, where 
culture and religion meet is given greater meaning too. Both communities are Muslim, both predominantly Sunni, but certain religious festivals are practiced differently in line with the cultural heritage of each. As is regularly demonstrated on a global scale, followers of Islam are not a homogenous collectivity but a disparate, differentiated and internally stratified cross-section of society (Hasan, 1997) and as the festival of Moharram reveals, Sunni Islam is itself deeply fissured ${ }^{12}$. The festival is held on the tenth day of the first month of the Islamic calendar to commemorate the matrydom of Hazrat Hussain, the grandson of the Prophet Mohammad. Although it is observed by some Bengali Muslims through private prayer it is considered a more minor event within the religious calendar and there is no public component. For North Indian immigrants in many parts of the world, however, the festival has long been of much greater importance (Vahed, 2002). Among Urdu-speaking Muslims in Bengal vast public celebrations are held in and around the camps for three days of the festival. It is the most visible expression of Urdu 'difference' within the year, and for many Bengalis in Dhaka this is the only time they are publicly confronted with the 'Urdu' presence. Having brought them together in East Bengal therefore religion has also become a dividing force.

As social divisions among 'Urdu-speakers' have grown, the festival of Moharram has come to represent cultural divisions among 'Urdu-speakers' as well. In Dhaka 'insiders' and 'outsiders' celebrate the festival quite differently. Those in the camps follow the 'traditional Bihari celebrations', including the public procession of a 'tajia', the dressing of boys as 'paikis' 13 , the waving of flags, and the banging of drums. They play ritual games which include fireplay, the 'bana' (where a stick is moved around the body while impromptu poetic questions are recited), and the 'jharra' (the beating of brooms to a rhythm, alongside the singing of specific Moharram songs). Those living outside the camps, on the other hand, very often celebrate Moharram as Bengalis do, either as a small private festival observed at home through prayer or not at all:

My brothers who live outside the camp only celebrate the two Eids, but I celebrate all the Bihari festivals...in the place where my brothers live now they don't even know what Moharram is! (Salima, 'insider', 40, Dhaka)

People in the camps and outside regularly explain that 'Urdu-speakers' in the region are particularly religious. Although historical links with Jamaat-i-Islami are diminishing, public perception of a connection remains strong. However, the 'religiosity' of camp residents is specific in its construction and, in its specificity it once again divides 'Urdu-speakers' in social space. The camps are thought to harbour 'traditional' and 'conservative' religious sentiment and many of the 'Bengalised' 'Urdu-speakers' who have moved outside consider the public celebrations of Moharram an example of the fanatical or exaggerated religious passions located within. These public celebrations are regularly described as the 'cultural programme' and considered by some 'outsiders' a distraction from the religious observation required. They are considered an aberration of pan-Islamic practice; a corrupted, distorted syncretic religious form. By blurring the boundaries between religion and culture, 'illeducated' 'camp-dwellers' are thought to be contaminating the purity of religious devotion, practicing religion in the 'wrong' way:

Those who are living outside they do not want to show that they are Urdu-speakers. That is why they celebrate the cultural programme less. (In the camps) the uneducated new generation are adopting the cultural programme from their ancestors ...they are celebrating Moharram in the wrong manner. They are beating drums and that is very wrong (Chanda, 'in between', 25, Dhaka). 
(Since moving from the camp) I can pray more now, because I have clean space to pray. We used to celebrate all the Urdu cultural practices like Moharram, but now less, just the religious ones...The camp dwellers do not follow the religious rule, they do not know about religious customs so they are not practicing properly. They celebrate the cultural programme because they are uneducated they do not know they are not part of religion (Sarbary, 'in between', 50+, Dhaka - emphasis added).

As Sarbary suggests, the dirt associated with the camps is in itself disruptive of worship. Dirt, of course, represents a contravention of ordered relations (Douglas, 1966) and here in the camps, dirt and culture contaminate the moral order contained within. Hashmi (2004) argues that increasingly in Bangladesh the so-called 'little traditions' of Islam have been juxtaposed against urban elite forms, considered the custodian of religion in the country. For those outside the camps, adopting urban elite forms was part of the process of integration and 'improvement' to which cultural capital was attached. As one 'in-betweener' explained:

We are following urban, middle class, Bengali culture, we are modern people. We do not follow Bihar's conservative cultural practices...Those who move out are the more progressive ('khula huwa') people (Emran, 'in between', 37, Dhaka).

In contrast to Bihar's apparently 'backward', conservative, cultural formations, an extraBengal 'Islamist' position is considered the position of 'progressivity'. In observation of Moharram, the 'right' and the 'wrong' was a passionately fought debate, and 'culture' here traditional, profane and syncretic - has become a polluting force. Perhaps paradoxically, constructions of modernity have often relied on the figure of the 'primitive', with cultural practices diametrically at odds with those of 'modern man' (Robinson, 2006). As Laclau (1990) observed, the historical conjuncture of the modern depends on these constitutive outsides. Accordingly, the camp is constructed as parochial, primitive and fanatic; the natural, pre-political, primordial stage of 'community' that must be superseded for 'freedom' and 'progress' to begin (Chatterjee, 1993).

The increasing role of religion in Bangladeshi politics does not mean that attachment to the Bengali language and culture has diminished. Today, religion and a Bengali cultural and linguistic tradition operate side-by-side as the two broad foci of Bangladeshi nationalist identity. The construction of those in the camp as motivated by syncretic cultural traditions, fluent only in a hybrid or pigeon linguistic form, and their juxtaposition against 'educated sections' with a mastery of Bengali linguistic and religious culture, shows however that today their marginalization is rooted in both.

\section{Conclusion}

Large-scale displacement lay at the foundation of both Pakistan and Bangladesh and defining the relationship between those displaced and the nation-state has not been straightforward. For the 'Urdu-speaking minority' in present-day Bangladesh, sixty years of political transition has seen identities formed and re-formed in space and time. In recent years religion has returned to the political scene and it has been assumed that, in appeals to a 'Muslim brotherhood', an opening has been created for 'Urdu-speaking Muslims' too. Contrary to expectations, however, 'modern pan-Islamic religious culture' is not a culture that all 'Urduspeakers' can claim. As the national project develops it is only those who live outside the camps, the 'educated sections' of 'Urdu-speaking society', who are accepted into the nation, 
while the 'syncretic traditions' and 'pre-modern religious passions' of the camp remain a polluting force.

While much has changed in East Bengal since Partition, I contend that certain discursive registers have lost little of their power. The narratives of informants speak to these discourses, and in their contemporary elaboration the true contours of acceptance and belonging in Bangladesh are drawn. Social, economic and cultural integration with the country's Bengali majority reflect capital movements in social space through which acceptance in the national life of Bangladesh is achieved. As this article demonstrates, the language of 'integration' is embedded in colonial narratives of 'population' versus 'peoplenation', 'community' versus 'citizen' which structure exclusion not only through language and ethnicity but through poverty and social space. Moreover, colonial and postcolonial registers transect and overlap. Today, colonial constructions of 'modernity' and 'progress' fold into religious discourses of 'pollution' and 'purity'; disseminating modes of reasoning that structure everyday life. The voices of minorities navigating claims to belonging through these discourses helps us understand the shifting landscape of national belonging in contemporary Bangladesh and the complicated accommodations this requires.

The Bangladeshi national project is young and not yet finished, and in such a context displaced populations remain problematic. As Samaddar (1999) argues, the protection of minorities has become a catchword for the liberal agenda in South Asia, but its complexities are often ignored. Such protection is impossible in the context of 'nationalizing states' which go on producing minorities and majorities of necessity. While spatial boundaries have separated those included from those excluded, therefore, space conceals something more troubling. Those considered capable of inclusion in the nation are those better able to hide their Urdu ancestry, in public if not in private; those less problematic to the project of a 'nationalizing state' which still depends on the marginalization of 'others' (Samaddar 1999).

\section{Acknowledgements}

I would like to thank the Bonnart-Braunthal Trust, the British Academy and the Sir Ernest Cassel Educational Trust for funding the research. I would also like to thank Al Falah Bangladesh, the Shamshul Huque Foundation and OBAT for their support during fieldwork, as well as two anonymous reviewers for some excellent suggestions.

\section{Notes}

\footnotetext{
${ }^{1}$ Passing as Bengali is possible (see Redclift, 2013a)

${ }^{2}$ The term has been translated variously as 'religious migrant' or 'religious refugee' although a direct translation into English is not possible.

${ }^{3}$ Some suggest this term literally means 'from the state of Bihar', while others suggest it comes from the Bengali word for 'outside' ('bahire').

${ }^{4}$ This is thought to include the rape, torture and murder of Bengalis. A War Crimes Tribunal was set up in 2010 by the ruling Awami League Government and the country has been marred by violence ever since.

${ }^{5}$ Not having migrated to Bengal 'for fear of persecution' (a position many would challenge), they effectively became refugees in the country in which many had resided for 60 years or more.

6 The International Statelessness Conventions of 1954 and 1961 only place an obligation on states to eliminate 'statelessness' in nationality laws and practice. Unlike the 1951 UN Convention on the Status of Refugees, these conventions attracted few ratifications or accessions for decades (Bangladesh has ratified neither). For many years 'statelessness' remained a minor interest within UNHCR and, without sufficient international attention, or clearer guidelines and agreed definitions, it was not taken seriously on the international stage.

${ }^{7}$ The camps in Mohammadpurmbenefit from a central location and Geneva Camp borders one of the busiest markets in the capital. Camp dwellers here make much of their money in trade and the internal economy of the
} 
camp is relatively buoyant. Camps in Mirpur and Saidpur are more deprived economically, with less local employment and a greater concentration of jobs in declining sectors (such as handiwork).

${ }^{8}$ As Article Nine of the Constitution of Bangladesh 1972 reveals 'The unity and solidarity of the Bangalee nation, which, deriving its identity from its language and culture, attained sovereign and independent Bangladesh...shall be the basis of Bangalee nationalism.' This article was repealed in 1977.

${ }^{9}$ An Islamic political party which strongly opposed an independent Bangladesh and was consequently banned after the war, but which emerged again as a legitimate organisation after the overthrow of the Mujib Government in the latter part of 1975.

${ }^{10}$ Widespread corruption and deeply rooted failures of 'governance' had pushed the country to the brink of social and political collapse (Lewis, 2011).

${ }^{11}$ Approximately $80 \%$ of all adult 'Biharis', or 184,000 persons, were registered as voters following voter registration drives ahead of the elections (Redclift, 2013a).

${ }_{12}$ Moharram is also a very important Shia festival.

${ }^{13}$ During Moharram Urdu-speaking boys are dressed as Hazrat Hussain. For three days of the festival they run through the city in his honour, redeeming their parents vows.

\section{References}

Ahmed, S.J. 2002. "Bengali nationalism through the sociology of theatre", In Bangladesh on the threshold of the twenty-first century, edited by A.M.Choudhury and F.Alam,. Dhaka: Asiatic Society of Bangladesh.

Ahmed, I., A. Dasgupta and K.Sinha-Kerkhoff, eds. 2004. State, society and displaced people in South Asia. Dhaka: University Press.

Al Falah Bangladesh. 2006. Urdu-speaker Settlements (and Population) in Bangladesh, 2006. Dhaka: Al Falah Bangladesh.

Ansari, S., 2005. Life after Partition: Migration, community and strife in Sindh, 1947-1962. Oxford: Oxford University Press.

Bloemraad, I., 2000. "Citizenship and immigration: A current review". Journal of international migration and integration, 1(1), 9-37.

Hansen, T.B, 1999. The saffron wave: Democracy and Hindu nationalism in modern India. Princeton, NJ: Princeton University Press.

Bourdieu, P., 1986. "The forms of capital". In Handbook of theory and research for the sociology of education, edited by J.G.Richardson. New York: Greenwood Press, 24158.

Brubaker, R., 2012. "Language, religion and the politics of difference". Nations and nationalism, 19 (1), 1-20.

Chatterjee, P., 1993. The nation and its fragments: Colonial and postcolonial histories. Princeton, NJ: Princeton University Press.

Chatterjee, P., 2005. "Sovereign violence and the domain of the political". In Sovereign bodies: Citizens, migrants and states in the postcolonial world, edited by T.B.Hansen and F.Stepputat. Princeton, NJ: Princeton University Press, 82-102.

Chatterji, J., 2010. "Migration myths and the mechanics of assimilation: Two community histories from Bengal". Studies in the humanities and the social sciences, 2 (1).

Daiya, K., 2008. Violent belongings: Partition, gender and national culture in postcolonial India. Philadelphia, PA: Temple University Press.

Douglas, M., 1966. Purity and danger: An analysis of the concepts of pollution and taboo. London: Routledge.

Ghosh, P., 2004. Unwanted and uprooted: a political study of migrants, refugees, stateless and displaced of South Asia. New Delhi: Samskriti.

Hasan, M., 1997. Islam, communities and the nation: Muslim identities in South Asia and beyond. New Delhi: Manohar. 
Hashmi, T.I., 2004. "Islamic resurgence in Bangladesh: Genesis, dynamics and implications". In Religious radicalism and security in South Asia, edited by S.P.Limaye, M.Malik and R.G.Wirsing. Honolulu: Asia Pacific Centre for Security Studies, 35-72.

Ilias, A., 2003. The Indian émigrés in Bangladesh: An objective analysis. Saidpur, Bangladesh: Shamshul Huque Foundation.

Isin, EF., 2005. "Citizenship after orientalism”. In Challenges to citizenship in a globalizing world: European questions and Turkish experiences, 31-51, edited by F.Keyman and A.Icduygu. London: Routledge.

Kabeer, N., 2002. "Citizenship, affiliation and exclusion: Perspectives from the South". IDS Bulletin, 33 (2), 1-15.

Kabir, M.G., 1987. "Religion, language and nationalism in Bangladesh". Journal of contemporary Asia, 17 (4), 473-87.

Kamaluddin A.F.M., 1985. "Refugee problems in Bangladesh". In: L.A Kosinski and E.K.Maudood, eds., Population redistribution and development in South Asia. Dordrecht: Riedel.

Keith, M., 2005. "Racialization and the public spaces of the multicultural city". In Racialization: Studies in theory and practice, 251-72, edited by M.Karim and J.Solomos, eds., Oxford: Oxford University Press.

Laclau, E., 1990. New reflections on the revolution of our time. London: Verso.

Lewis, D., 2011. Bangladesh: Politics, economy and civil society. Cambridge: Cambridge University Press.

Malkki, L.H., 1995. Purity and exile: Violence memory and national cosmology among Hutu refugees in Tanzania. Chicago, IL: University of Chicago Press.

Osmany, S.H., 1992. Bangladeshi nationalism: History of dialectics and dimensions. Dhaka, Bangladesh: University Press Ltd.

Paulsen, E., 2006. "The citizenship status of the Urdu-Speakers/Biharis in Bangladesh". Refugee survey quarterly, 25 (3), 54-69.

Rahman, M., 2003. A community in transition: The Biharis in Bangladesh. Dhaka: ELCOP.

Rahman, M. and W.Van Schendel, 2004. "I am not a refugee: Rethinking Partition's migrants". In State, society and displaced people in South Asia, 207-43, edited by I.Ahmed, A.Dasgupta and K.Sinha-Kerkoff. Dhaka: University Press.

Redclift, V.M., 2011. "Subjectivity and citizenship: Intersections of space, ethnicity and identity among the Urdu-speaking minority in Bangladesh", Journal of International Migration and Integration, 12 (1), 25-42.

Redclift, V.M., 2013a. Statelessness and citizenship: Camps and the creation of political space. London: Routledge.

Redclift, V.M., 2013b. "Abjects or agents? Camps, contests and the creation of political space". Citizenship Studies, 17 (3-4), 293-306.

Refugees International, 2008. Futures denied: 'statelessness' among infants, children and youth. Washington: Refugees International.

Robinson, J., 2006. Ordinary cities: Between modernity and development. London: Routledge.

Roy, A., 2001. "Being and becoming a Muslim: A historiographic perspective on the search for a Muslim identity in Bengal". In Bengal, rethinking history: Essays in historiography, edited by S.Bandyopadhyay. New Delhi: Manohar.

Samaddar, R., 1999. The marginal nation: Transborder migration from Bangladesh to West Bengal. London: Sage.

Samaddar, R., 2002. Paradoxes of the nationalist time: Political essays on Bangladesh. Dhaka: The University Press. 
Skeggs, B., 1997. Formations of class and gender: Becoming respectable. London: Sage.

Vahed, G., 2002. "Constructions of community and identity among Indians in colonial Natal 1860-1910: The role of the muharram festival". The Journal of African History, 43 (1), 77-93.

Verkaaik, O., 2001. "The captive state: Corruption, intelligence agencies and ethnicity in Pakistan". In States of imagination: Ethnographic explorations of the postcolonial state, 345-64, edited by T. B. Hansen and F.Stepputat. Durham, NC: Duke University Press.

Yuval-Davis, N., F.Anthias, F. And E.Kofman, 2005. "Secure borders and safe haven and the gendered politics of belonging: Beyond social cohesion". Ethnic and racial studies, 28(3), 513-35.

Zamindar, V., 2007. The long Partition and the making of modern South Asia: Refugees, boundaries and histories. New York: Colombia University Press.

VICTORIA REDCLIFT is Lecturer in Sociology at the University of Surrey.

ADDRESS: Department of Sociology, University of Surrey, Guildford, GU2 7XH 